Brit. Heart J., 1965, 27, 876.

\title{
EFFECT OF MORPHINE ON PULMONARY BLOOD VOLUME IN CONVALESCENTS FROM HIGH ALTITUDE PULMONARY GEDEMA
}

BY

\author{
SUJOY B. ROY, INDER SINGH, M. L. BHATIA, AND P. K. KHANNA \\ From the Directorate General, Armed Forces Medical Services, New Delhi-11, India \\ Received April 5, 1965
}

Morphine proved effective when anxiety, restlessness, and laboured breathing associated with high altitude pulmonary œdema did not respond satisfactorily to oxygen therapy (Singh et al., 1965).

Pharmacologically, no primary effect of morphine on the pulmonary circuit in man has so far been demonstrated (Daley, Goodwin, and Steiner, 1960). However, more than one explanation exists for the beneficial effect of morphine in pulmonary œdema: (1) morphine helps to reduce the central venous pressure by allaying anxiety and restlessness, (2) morphine suppresses the respiratory centre and relieves the sensation of suffocation, (3) in laboured breathing there is considerable negativity of intrathoracic pressures; this causes the alveolar blood vessels to collapse, thus impeding the oxygenation of blood: morphine abolishes this by restoring normal breathing.

In 18 subjects, convalescing from high altitude pulmonary œdema, hæmodynamic studies revealed that in the majority pulmonary blood volume remained increased for 3 to 24 weeks after they had been evacuated to the plains and relieved of their symptoms. This was not so in 25 healthy male controls of comparable age and occupation. It occurred to us that the beneficial effect of morphine in patients with high altitude pulmonary œdema may result from reduction of pulmonary blood volume. This report, which records the effects of intracardiac morphine on the pulmonary blood volume and circulatory dynamics in four convalescents from high altitude pulmonary œdema, lends support to our idea.

\section{SubJECTS AND METHODS}

Studies were made on 4 men, 21 to 28 years old, all plainsmen. Three of them were resident at high altitude, 11,500 to 13,000 feet, for 137 to 180 days, but on return to high altitudes after spending 43 to 226 days in the plains, they developed acute pulmonary œdema within 24 to 48 hours of arrival. With treatment the lungs cleared in 4 to 6 days, and on recovery, they were evacuated to the plains. The fourth man had been recently introduced to high altitudes and he developed acute pulmonary odema on the fifth day of arrival. His lungs cleared within $\mathbf{4 8}$ hours, and like the rest, he was evacuated to the plains.

Cardiac catheterization was carried out 20 to 67 days after recovery from pulmonary œdema. Before catheterization they were all asymptomatic, had normal pulmonary second sounds, and their lungs were clear; two of them showed slight prominence of the pulmonary artery on radiographs; and one had tall $\mathrm{T}$ waves in leads V1, V2, and V3.

The subjects were studied in the fasting state without sedation. Right heart catheterization was performed by positioning a No. 7 cardiac catheter in the pulmonary artery just beyond the valve. The left atrium was entered by percutaneous transseptal Brockenbrough method (Brockenbrough and Braunwald, 1960 ) as practised in our laboratory (Roy, Bhatia, and Guleria, 1963). The right femoral artery was cannul- 
TABLE

EfFect of Morphine on Pulmonary Blood Volume and Circulatory Dynamics in 4 Convalescents from High Altitude Pulmonary cedema

\begin{tabular}{|c|c|c|c|c|c|c|c|c|c|c|c|c|c|c|c|c|c|c|c|}
\hline \multirow{3}{*}{$\begin{array}{l}\text { Case } \\
\text { No. }\end{array}$} & \multirow{3}{*}{$\begin{array}{c}\text { Basal } \\
\text { surface } \\
\text { area } \\
\left(\mathrm{m} . .^{2}\right)\end{array}$} & \multirow{3}{*}{$\begin{array}{l}B^{*} \text {. } \\
\text { and } \\
\text { A } \dagger\end{array}$} & \multicolumn{8}{|c|}{ Pressure (mm. Hg) } & \multirow{3}{*}{$\begin{array}{c}\text { HR } \\
\text { per } \\
\text { min. }\end{array}$} & \multirow{3}{*}{$\begin{array}{c}\mathrm{CI} \\
(1.1 \\
\min .1 \\
\left.\mathrm{~m} .{ }^{2}\right)\end{array}$} & \multirow{3}{*}{$\left|\begin{array}{c}\text { SI } \\
(\text { ml./. } \\
\text { beat// } \\
\left.\text { m }^{2} .\right)\end{array}\right|$} & \multirow{3}{*}{$\begin{array}{c}\text { PVR } \\
\text { (mm. } \\
\text { Hg/l./ } \\
\text { min. } . / \\
\text { m.2) }\end{array}$} & \multirow{3}{*}{$\begin{array}{c}\text { SVR } \\
\text { (mm. } \\
\text { Hg/l.l } \\
\text { min.l } \\
\text { m.2) }\end{array}$} & \multirow{2}{*}{\multicolumn{2}{|c|}{$\begin{array}{c}\text { Ventricular } \\
\text { work } \\
\text { (kg.m./min./ } \\
\text { m.2) }\end{array}$}} & \multirow{3}{*}{$\begin{array}{c}\text { Central } \\
\text { blood } \\
\text { volume } \\
(\mathrm{ml} . / \\
\left.\mathrm{m} .{ }^{2}\right)\end{array}$} & \multirow{3}{*}{$\begin{array}{l}\text { Pulmo- } \\
\text { nary } \\
\text { blood } \\
\text { volume } \\
(\mathrm{ml} .1 \\
\mathrm{m.2})\end{array}$} \\
\hline & & & \multicolumn{3}{|c|}{ Femoral artery } & \multicolumn{3}{|c|}{ Pulmonary artery } & \multirow{2}{*}{$\underset{\text { (mean) }}{\mathbf{R A}}$} & \multirow{2}{*}{$\underset{\text { (mean) }}{\text { LA }}$} & & & & & & & & & \\
\hline & & & $\mathbf{s}$ & D & $\mathbf{M}$ & $\mathbf{s}$ & D & $\mathbf{M}$ & & & & & & & & Right & Left & & \\
\hline 1 & 1.67 & $\begin{array}{l}\mathbf{B} \\
\mathbf{A}\end{array}$ & $\begin{array}{l}153 \\
140\end{array}$ & $\begin{array}{l}78 \\
70\end{array}$ & $\begin{array}{l}115 \\
105\end{array}$ & $\begin{array}{l}26 \\
17\end{array}$ & $\begin{array}{r}10 \\
9\end{array}$ & $\begin{array}{l}17 \\
13\end{array}$ & $\begin{array}{l}1.0 \\
0.5\end{array}$ & $\begin{array}{l}4.0 \\
1.5\end{array}$ & $\begin{array}{r}100 \\
84\end{array}$ & $\begin{array}{l}5.8 \\
4.1\end{array}$ & $\begin{array}{l}58 \\
49\end{array}$ & $\begin{array}{l}2 \cdot 2 \\
2 \cdot 1\end{array}$ & $\begin{array}{l}19 \cdot 7 \\
25 \cdot 4\end{array}$ & $\begin{array}{l}2 \cdot 1 \\
1.0\end{array}$ & $\begin{array}{r}12.4 \\
8.2\end{array}$ & $\begin{array}{r}1102 \\
786\end{array}$ & $\begin{array}{l}397 \\
335\end{array}$ \\
\hline 2 & 1.66 & $\begin{array}{l}\mathbf{B} \\
\mathbf{A}\end{array}$ & $\begin{array}{l}135 \\
110\end{array}$ & $\begin{array}{l}80 \\
72\end{array}$ & $\begin{array}{r}102 \\
90\end{array}$ & $\begin{array}{l}20 \\
18\end{array}$ & $\begin{array}{l}9 \\
8\end{array}$ & $\begin{array}{l}14 \\
12\end{array}$ & $\begin{array}{l}2 \cdot 0 \\
0\end{array}$ & $\begin{array}{l}6.0 \\
4.0\end{array}$ & $\begin{array}{l}90 \\
90\end{array}$ & $\begin{array}{l}4.1 \\
3.9\end{array}$ & $\begin{array}{l}46 \\
43\end{array}$ & $\begin{array}{l}2 \cdot 0 \\
2 \cdot 1\end{array}$ & $\begin{array}{l}24 \cdot 4 \\
23 \cdot 1\end{array}$ & $\begin{array}{l}1.1 \\
1.0\end{array}$ & $\begin{array}{l}7.7 \\
5.9\end{array}$ & $\begin{array}{l}956 \\
902\end{array}$ & $\begin{array}{l}198 \\
156\end{array}$ \\
\hline 3 & 1.65 & $\begin{array}{l}\mathbf{B} \\
\mathbf{A}\end{array}$ & $\begin{array}{l}120 \\
110\end{array}$ & $\begin{array}{l}72 \\
70\end{array}$ & $\begin{array}{l}88 \\
85\end{array}$ & $\begin{array}{l}23 \\
20\end{array}$ & $\begin{array}{l}7 \\
7\end{array}$ & $\begin{array}{l}13 \\
12\end{array}$ & $\begin{array}{l}3.0 \\
2.5\end{array}$ & $\begin{array}{l}4.0 \\
4.0\end{array}$ & $\begin{array}{l}90 \\
80\end{array}$ & $\begin{array}{l}7.8 \\
6.6\end{array}$ & $\begin{array}{l}87 \\
83\end{array}$ & $\begin{array}{l}1.2 \\
1.2\end{array}$ & $\begin{array}{l}10.9 \\
12.5\end{array}$ & $\begin{array}{l}2.2 \\
1.7\end{array}$ & $\begin{array}{l}13.0 \\
10.0\end{array}$ & $\begin{array}{l}1573 \\
1202\end{array}$ & $\begin{array}{l}468 \\
278\end{array}$ \\
\hline 4 & 1.66 & $\begin{array}{l}\mathbf{B} \\
\mathbf{A}\end{array}$ & $\begin{array}{l}128 \\
119\end{array}$ & $\begin{array}{l}77 \\
62\end{array}$ & $\begin{array}{l}94 \\
83\end{array}$ & $\begin{array}{l}38 \\
34\end{array}$ & $\begin{array}{l}17 \\
14\end{array}$ & $\begin{array}{l}22 \\
20\end{array}$ & $\begin{array}{l}6.0 \\
5.0\end{array}$ & $\begin{array}{r}10.0 \\
9.0\end{array}$ & $\begin{array}{l}54 \\
50\end{array}$ & $\begin{array}{l}3 \cdot 1 \\
2 \cdot 8\end{array}$ & $\begin{array}{l}57 \\
56\end{array}$ & $\begin{array}{r}3.9 \\
3.9\end{array}$ & $\begin{array}{l}28.4 \\
27.9\end{array}$ & $\begin{array}{l}1.4 \\
1.2\end{array}$ & $\begin{array}{l}5 \cdot 3 \\
4 \cdot 4\end{array}$ & $\begin{array}{l}775 \\
765\end{array}$ & $\begin{array}{l}285 \\
233\end{array}$ \\
\hline & Average & $\begin{array}{l}\mathbf{B} \\
\mathbf{A}\end{array}$ & $\begin{array}{l}134 \\
120\end{array}$ & $\begin{array}{l}77 \\
69\end{array}$ & $\begin{array}{r}100 \\
91\end{array}$ & $\begin{array}{l}27 \\
22\end{array}$ & $\begin{array}{r}11 \\
9\end{array}$ & $\begin{array}{l}17 \\
14\end{array}$ & $\begin{array}{l}3.0 \\
2 \cdot 0\end{array}$ & $\begin{array}{l}6 \cdot 0 \\
4.5\end{array}$ & $\begin{array}{l}84 \\
76\end{array}$ & $\begin{array}{l}5.2 \\
4.4\end{array}$ & $\begin{array}{l}62 \\
58\end{array}$ & $\begin{array}{l}2 \cdot 3 \\
2 \cdot 3\end{array}$ & $\begin{array}{l}20.9 \\
22 \cdot 2\end{array}$ & $\begin{array}{l}1.7 \\
1.2\end{array}$ & $\begin{array}{l}9 \cdot 6 \\
7 \cdot 2\end{array}$ & $\begin{array}{r}1102 \\
889\end{array}$ & $\begin{array}{l}337 \\
251\end{array}$ \\
\hline Norm & $\begin{array}{l}\text { nal values } \\
\text { Range } \\
\text { Average }\end{array}$ & & $\begin{array}{l}110- \\
130 \\
120\end{array}$ & $\begin{array}{l}50- \\
80 \\
70\end{array}$ & $\begin{array}{c}70- \\
100 \\
85\end{array}$ & $\begin{array}{l}13- \\
30 \\
21\end{array}$ & $\begin{array}{c}5- \\
13 \\
9\end{array}$ & $\begin{array}{c}7- \\
19 \\
13\end{array}$ & $\begin{array}{l}0.5- \\
6.0 \\
3.7\end{array}$ & $\begin{array}{c}2.0- \\
11.0 \\
4.0\end{array}$ & $\begin{array}{c}105 \\
65 \\
85\end{array}$ & $\begin{array}{l}2 \cdot 5- \\
5 \cdot 0 \\
4 \cdot 1\end{array}$ & $\begin{array}{l}22- \\
70 \\
49\end{array}$ & $\begin{array}{l}0-\cdot 3 \\
2 \cdot 0 \\
1 \cdot 1\end{array}$ & $\begin{array}{l}12- \\
38 \\
21 \cdot 4\end{array}$ & $\begin{array}{l}0 \cdot 7- \\
1 \cdot 3 \\
1 \cdot 1\end{array}$ & $\begin{array}{l}4 \cdot 4-4 \\
8.7 \\
7 \cdot 1\end{array}$ & $\begin{array}{c}407- \\
1473 \\
960\end{array}$ & $\begin{array}{l}145- \\
310 \\
210\end{array}$ \\
\hline
\end{tabular}

* B, before morphine. $\quad+$ A, after morphine.

$\ddagger$ Normal values were obtained in our laboratory by studying 25 healthy male volunteers of comparable age and occupation.

S, systolic; D, diastolic; M, mean.

RA, right atrium; LA left atrium; HR, heart rate; CI, cardiac index; SI, stroke index; PVR, pulmonary vascular resistance; SVR, systemic vascular resistance.

ated to obtain arterial blood pressure and dye curves. Consecutive dye dilution curves were obtained directly on a polyviso channel through a continuous recording densitometer (Colson) by injecting $25 \mathrm{ml}$. of 0.5 per cent indigo-carmine dye into the main pulmonary artery and then into the left atrium. The difference in the mean transit times of the two resulting curves was taken as pulmonary transit time. The cardiac output was measured from the dilution curves by Hamilton et al.'s formula (1932). The volume of blood between the pulmonary artery and the left atrium was calculated by multiplying the pulmonary mean transit time by the average cardiac output and represented the pulmonary blood volume. The intracardiac and femoral arterial pressures were recorded through P23 Db strain gauge manometers on a 4-channel single gun photographic system. The base-line for all pressure measurements was taken as half the chest thickness at the second costal cartilage with the patient supine (Roy, Gadboys, and Dow, 1957). After obtaining the control data, $10 \mathrm{mg}$. of morphine sulphate was injected as a single bolus into the pulmonary artery. Continuous pulmonary arterial and left atrial pressures were recorded for 15 minutes, and then a second set of cardiac output, pulmonary blood volume, and pressure measurements was obtained.

\section{RESULTS}

Details of cardiac catheterization data are given in the Table.

The pulmonary blood volume was found to be significantly increased in two men (Cases 1 and 3) and was within normal range in the other two. The central blood volume was raised only in one (Case 3) and was within the normal range in the rest. Intracardiac morphine caused a 15 to 40 per cent (average 26\%) decrease in the pulmonary blood volume in all cases while the central blood volume decreased significantly only in two (Cases 1 and 3).

The heart rate, cardiac index, and stroke index of Cases 2 and 4 did not change after administration of morphine, whereas a moderate decrease was noticed in the other two. The femoral arterial, pulmonary arterial, and both the ventricular filling pressures showed a slight fall with morphine, but the change was not significant. Administration of morphine did not alter the pulmonary vascular 
resistance but increased somewhat the systemic vascular resistance in Cases 1 and 3. Calculated work of both the ventricles appeared to decrease after morphine.

\section{DisCUSSION}

In 5 subjects with high altitude pulmonary œdema, who were studied within 12 to 72 hours of the episode (Fred et al., 1962; Hultgren et al., 1964), the pulmonary blood volume was not estimated. In convalescents, however, the pulmonary blood volume has been found to be increased for several weeks. It is probable that during œdema this increase is considerable.

From our study it is apparent that morphine decreases the pulmonary blood volume. The four patients when studied were convalescing and were free from anxiety, restlessness, sense of suffocation, or laboured breathing: so the effect of morphine was achieved independently of its influence on these.

The slight reduction in the ventricular filling pressures together with the slight decrease in cardiac output suggests that the beneficial effect of morphine is due to a redistribution of blood in the periphery.

\section{SUMMARY}

Data are given on the immediate effect of intracardiac morphine on the pulmonary blood volume and circulatory dynamics in four patients convalescing from high altitude pulmonary œdema.

The immediate hæmodynamic response was reduction in the pulmonary blood volume, cardiac output, stroke index, systemic arterial pressure, and filling pressures and work load of both the ventricles. It is felt that the beneficial effect of intravenous morphine in patients with high altitude pulmonary œdema may partly result from reduction of the pulmonary blood volume.

We are grateful to Lt.-General T. R. Pahwa, Director General, Armed Forces Medical Services, for permission to publish this paper.

\section{REFERENCES}

Brockenbrough, E. C., and Braunwald, E. (1960). A new technic for left ventricular angiocardiography and transseptal left heart catheterization. Amer. J. Cardiol., 6, 1062.

Daley, R., Goodwin, J. F., and Steiner, R. E. (1960). Clinical Disorders of the Pulmonary Circulation. Churchill, London.

Fred, H. L., Schmidt, A. M., Bates, T., and Hecht, H. H. (1962). Acute pulmonary edema of altitude. Clinical and physiologic observations. Circulation, 25, 929.

Hamilton, W. F., Moore, J. W., Kinsman, J. M., and Spurling, R. G. (1932). Studies on the circulation. IV. Further analysis of the injection method, and of changes in hemodynamics under physiological and pathological conditions. Amer. J. Physiol., 99, 534.

Hultgren, H. N., Lopez, C. E., Lundberg, E., and Miller, H. (1964). Physiologic studies of pulmonary edema at high altitude. Circulation, 29, 393.

Roy, S. B., Bhatia, M. L., and Guleria, J. S. (1963). Percutaneous transseptal left heart catheterization. Indian Heart $J ., 15,255$.

- Gadboys, H. L., and Dow, J. W. (1957). Base line for left heart catheterization. Amer. Heart J., 54, 753.

Singh, I., Kapila, C. C., Khanna, P. K., Nanda, R. B., and Rao, B. D. P. (1965). High altitude pulmonary edema. Lancet, 1, 229. 